\title{
Swiss Life Sciences - A Science Communication Project for Both Schools and the Wider Public Led by the Foundation Science et Cité
}

\author{
Michael Röthlisberger*
}

\begin{abstract}
The foundation Science et Cité was founded 1998 with the aim to inform the wider Swiss public about current scientific topics and to generate a dialogue between science and society. Initiated as an independent foundation by the former State Secretary for Science and Research, Dr. Charles Kleiber, Science et Cité is now attached to the Swiss Academies of Arts and Sciences as a competence center for dialogue with the public. Due to its branches in all language regions of the country, the foundation is ideally suited to initiate and implement communication projects on a nationwide scale. These projects are subdivided into three categories: i) science communication for children/adolescents, ii) establishing a dialogue between science and the wider public, and iii) conducting the role of a national center of competence and networking in science communication. Swiss Life Sciences is a project that fits into all of these categories: a year-round program for schools is complemented with an annual event for the wider public. With the involvement of most of the major Swiss universities, the Swiss National Science Foundation, the foundation Gen Suisse and many other partners, Swiss Life Sciences also sets an example of national networking within the science communication community.
\end{abstract}

Keywords: Dialogue · Life Sciences · National · Science et Cité · Schools · Wider public

\section{Science et Cité}

The foundation Science et Cité ${ }^{[1]}$ was founded in 1998 with the aim to inform the wider Swiss public about scientific topics and to generate a dialogue between science and society. Within its 14 years of existence, the foundation has developed a broad network in the science communication community and a deep knowledge in project management of science communication and dialogue projects. Science et Cité does not financially support science communication projects proposed by others, but it organizes and implements communication projects itself.

Since January 2012, Science et Cité has been working closely with the Swiss Academies of Arts and Sciences. ${ }^{[2]}$ As their competence center for dialogue with the public, Science et Cité works in collaboration with the various thematic units

${ }^{*}$ Correspondence: Dr. M. Röthlisberger Stiftung Science et Cité

Marktgasse 50

$\mathrm{CH}-3011$ Bern

Tel.: +41313131919

E-mail: michael.roethlisberger@science-et-cite.ch of the academies (sciences, engineering, medicine, humanities and social sciences), depending on the different projects. With regional coordinators in Bern, Lausanne and Lugano, Science et Cité is active in all language regions of Switzerland and is thus able to organize and implement projects on a national scale.

During 2012 and in the years to come, there are several main projects running, each of which is carried out in collaboration with different partners. They are summarised in Table 1. The project 'Swiss Life Sciences' will be presented in more detail below.

\section{Swiss Life Sciences}

The project 'Swiss Life Sciences' arose as a follow-up of the 'Gene Days' or 'Tage der Genforschung', which were initiated by the foundation Gen Suisse in 1999.[5] Initially, events on the topic of genetic research for the wider public as well as for schools reached an audience of 600 people per year. The project 'Swiss Life Sciences' covers a broader spectrum of scientific subjects and reaches about 3'000 citizens per year at present.

The project consists of two main parts, a year-round offer for schools and an annual public event. Since teachers need the flexibility to fit lab-visits or meetings with scientists into their schedule, such events can be arranged flexibly throughout the year. The public, on the other hand, is generally attracted by bigger events on fixed dates. For the public part, the philosophy consequently is to organize few but bigger events, rather than many small ones scattered throughout the year.

Besides various organisational and financial partners, the most important of which are the Swiss Academies of Sciences and the Swiss National Science Foundation, [6] the project Swiss Life Sciences is supported by many different organizations, amongst them departments of most of the major Swiss universities. Science et Cité is in charge of the national coordination of all activities, as well as national communication, fundraising and support of the school program.

\section{Year-round Offer Exclusive to Schools}

As a whole year offer, school classes can exclusively visit laboratories, perform hands-on experiments or invite researchers to their classroom to get first-hand information about research in life sciences. Thereby, the pupils can experience what life sciences are all about and how research works in practice by meeting scientists face to face. Research topics covered 
Table 1. Overview of Science et Cité's main projects in 2012 and coming years

\begin{tabular}{|c|c|c|c|}
\hline Project name & Target audience & Content & Main partners \\
\hline $\begin{array}{l}\text { Swiss Life } \\
\text { Sciences }^{[3]}\end{array}$ & $\begin{array}{l}\text { Schools, all levels } \\
\text { Wider public }\end{array}$ & $\begin{array}{l}\text { Researchers in } \\
\text { Life Sciences visit } \\
\text { schools, school } \\
\text { classes get the } \\
\text { chance to see labo- } \\
\text { ratories, perform } \\
\text { experiments. } \\
\text { The wider public } \\
\text { has direct contact } \\
\text { with Life Science } \\
\text { researchers. A } \\
\text { dialogue between } \\
\text { research and society } \\
\text { is established. }\end{array}$ & $\begin{array}{l}\text { Swiss Acade- } \\
\text { mies of Arts and } \\
\text { Sciences, Swiss } \\
\text { National Science } \\
\text { Foundation, Gen } \\
\text { Suisse, several } \\
\text { Swiss universities, } \\
\text { Verein Forschung } \\
\text { für Leben, } \\
\text { USGEB }\end{array}$ \\
\hline Citizen Science & $\begin{array}{l}\text { Schools, all levels } \\
\text { Wider public }\end{array}$ & $\begin{array}{l}\text { School classes, as } \\
\text { well as the wider } \\
\text { public, collect data } \\
\text { on a large scale to } \\
\text { support research } \\
\text { projects. }\end{array}$ & $\begin{array}{l}\text { GLOBE, ETH } \\
\text { Zurich, Météo } \\
\text { Suisse, University } \\
\text { of Bern }\end{array}$ \\
\hline Café Scientifique ${ }^{[1]}$ & Wider public & $\begin{array}{l}\text { Experts from vari- } \\
\text { ous research fields } \\
\text { meet the public to } \\
\text { interactively discuss } \\
\text { current issues in } \\
\text { science and society. }\end{array}$ & $\begin{array}{l}\text { Local universities, } \\
\text { museums and uni- } \\
\text { versities of applied } \\
\text { sciences }\end{array}$ \\
\hline School train & Schools & $\begin{array}{l}\text { School classes visit } \\
\text { a special train that } \\
\text { offers information } \\
\text { and hands-on ex- } \\
\text { periments on the } \\
\text { subjects of mobility } \\
\text { and energy. }\end{array}$ & $\begin{array}{l}\text { Swiss Federal } \\
\text { Railways SBB, } \\
\text { Swiss Federal } \\
\text { Office of Energy } \\
\text { SFOE }\end{array}$ \\
\hline ScienceComm $^{[4]}$ & $\begin{array}{l}\text { Science communi- } \\
\text { cators }\end{array}$ & $\begin{array}{l}\text { Science communi- } \\
\text { cation and dialogue } \\
\text { experts meet to ex- } \\
\text { change experiences } \\
\text { and establish new } \\
\text { projects. Biggest } \\
\text { meeting of science } \\
\text { communicators in } \\
\text { Switzerland. }\end{array}$ & $\begin{array}{l}\text { Swiss Acade- } \\
\text { mies of Arts and } \\
\text { Sciences, Swiss } \\
\text { National Science } \\
\text { Foundation, Foun- } \\
\text { dation Mercator } \\
\text { Switzerland }\end{array}$ \\
\hline
\end{tabular}

include biotechnology, synthetic biology, neurology, oncology, nanotechnology or personalized medicine.

The offers are split into five regions (Basel, Bern, Geneva, Lausanne and Zurich) and the schools are presented with the opportunities available in their respective regions. Altogether, school teachers have the choice amongst almost 100 offers.

The school program is based on the offer of the former project 'Tage der Genforschung' and has been extended both thematically and spatially. Since 1999, approximately $20^{\prime} 000$ pupils have visited laboratories and/or have been visited by a scientist. A leading role in organizing the school visits and maintaining the offers by researchers is played by the foundation Gen Suisse. subject-related movies, a man-size model of a cell to study from the inside ${ }^{[7]}$ or handson experiments such as forensic DNA analyses of a virtual crime scene. There is, however, a constant need for change with regards to formats and contents.

As a further advancement, Swiss Life Sciences tries to establish events in smaller, non-university cities, in order to reach people who normally do not get in touch with science whatsoever.

\section{Target Audience and Rationale Behind the Project}

The year-round program is designed for school classes of various ages (approx. 9 to 19 years old). It has been shown that it is important to awaken the fascination for science, as for any other field, at a very early age in order to reach a sustainable interest in research. ${ }^{[8]}$ This is true for all disciplines of the MINT field (mathematics, information technology, natural sciences, and technology). Swiss Life Sciences delivers a substantial contribution to the national effort to recruit more adolescents for studies and positions in the MINT field, a challenge that is treated with high priority in Swiss politics. Furthermore, it is a goal of the project Swiss Life Sciences, and of Science et Cité in general, to try to reach people of social layers, who do not normally show any interest in scientific subjects.

The public event shall address the broader public in general. It is important to enhance the dialogue between research and public in order to establish mutual understanding and acceptance. As it has been shown in previous science festivals, a significant percentage of visitors is accompanied by their children (e.g. $41 \%$ for the festival basecamp09 by Science et Cité). Furthermore, a significant percentage of the visitors of science-public interactions often stems from a highly educated social layer. It is one of the main goals of Swiss Life Sciences, and of the foundation Science et Cité in general, to modify this situation and to establish contacts between science and all layers of society. To this end, Science et Cité is always interested in further projects and partnerships.

Received: September 25, 2012

[1] www.science-et-cite.ch

[2] www.akademien-schweiz.ch

[3] www.swiss-life-sciences.ch

[4] www.sciencecomm.ch

[5] www.gensuisse.ch

[6] www.snf.ch

[7] www.diezelle.ch

[8] 'Mangel an MINT-Fachkräften in der Schweiz. Ausmass und Ursachen des Fachkräftemangels in MINT (Mathematik, Informatik, Naturwissenschaften und Technik)', Bericht des Bundesrates, Schweizerische Eidgenossenschaft, August 2010. 